\title{
Atopic dermatitis and melanoma: A case-control study
}

\author{
Vivien Marasigan ${ }^{1 *}$, Marie-Anne Morren ${ }^{1}$, Julien Lambert ${ }^{2}$, Karen Medaer ${ }^{3}$, Steffen Fieuws ${ }^{4}$, Marjan Garmyn ${ }^{1}$ \\ From Methods in Epidemiology Symposium \\ Leuven, Belgium. 17 September 2015
}

\section{Background}

Atopic dermatitis (AD) has been linked to fewer nevi which implies a decreased risk for melanoma. Yet scarce studies have been conducted on the association between $\mathrm{AD}$ and melanoma.

\section{Aim}

To analyze the association of $\mathrm{AD}$ and melanoma development in a case-control population.

\section{Methods}

A cohort of cutaneous melanoma patients treated at the Department of Dermatology in University Hospitals Leuven and Antwerp University Hospital in Belgium were included. Cases and randomly selected controls were interviewed. The U.K. Working Party's diagnostic criteria for $\mathrm{AD}$ was utilized in the ascertainment of $\mathrm{AD}$. Cases were matched with controls on important confounders and gender. In addition to AD, personal atopy, respiratory atopy, active atopy and familial atopy, and their relation to melanoma development, were also investigated. Statistical analyses were performed using Mc Nemar's test and conditional logistic regression.

\section{Results}

188 cases and 596 controls were included. Analysis showed a general inverse association between atopy related outcome variables and melanoma development but only personal atopy was statistically significant $(\mathrm{OR}=0.53, \mathrm{CI}: 0.30-0.96, \mathrm{p}$-value $=0.04)$. A separate analysis showed that nevi count was the most important confounder. Therefore, a sub-analysis was conducted in the group with no or few moles whereby personal atopy remained statistically significant ( $\mathrm{p}$-value $=0.03$ ).

${ }^{1}$ University Hospitals Leuven, Leuven, Belgium

Full list of author information is available at the end of the article

\section{Conclusion}

This is a case-control study on the association between $\mathrm{AD}$ and melanoma using a valid $\mathrm{AD}$ questionnaire, suggesting an inverse association between personal atopy and melanoma when matched for important confounders. However, no strong claim can be made when corrected for multiple testing.

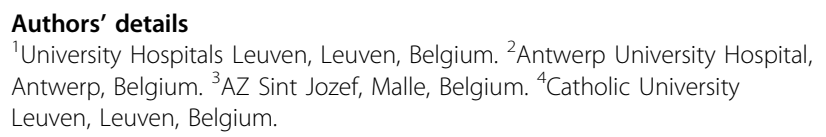

Published: 17 September 2015

doi:10.1186/2049-3258-73-S1-P1

Cite this article as: Marasigan et al:: Atopic dermatitis and melanoma: A case-control study. Archives of Public Health 2015 73(Suppl 1):P1.

\section{Submit your next manuscript to BioMed Central and take full advantage of: \\ - Convenient online submission \\ - Thorough peer review \\ - No space constraints or color figure charges \\ - Immediate publication on acceptance \\ - Inclusion in PubMed, CAS, Scopus and Google Scholar \\ - Research which is freely available for redistribution

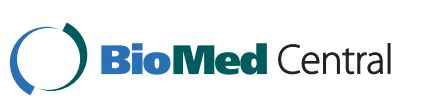

